\title{
日本語中上級学習者の作文に対する \\ 内容、言語形式を改善させる教師の訂正フィードバック \\ Efficacy of Corrective Feedback on Upper Intermediate JFL Student Writing
}

\section{飯田 由美 \\ 香港中文大学専業進修学院}

\section{要旨}

日本語作文教育において、作文添削は教師にとってかなりの負担となっている。し かしながら、従来の研究では教師の誤用訂正は効果ありとする研究（Chandler, 2003; Sachs \& Polio，2007）もあるが、日本語レベルが上位の学習者にはセルフモニタリン グ能力があり、誤用を自身で訂正できると報告している研究（石橋，2000；Qi \& Lapkin， 2001）もある。本稿では教師の添削負担を軽減し、かつ日本語中上級学習者の作文の 質を改善させる教師訂正および学習者の自己訂正の方法について、内容、言語形式両 面から明らかにすることを目的とし、以下の 2 つの調査を実施した。1)教師フィード バックとピア・レスポンスの違いは書き直し作文の内容面の改善にどのように影響す るか、2)教師のフィードバック方法（明示的、非明示的）の違いは、書き直し作文の 言語形式面の正確さにどのように影響するか。結果、1）教師フィードバックの方が内 容面の質の改善に効果があり、2）言語形式面では明示的訂正のほうが誤用修正率は高 かった。さらに言語形式を改善すると、構成面の質の改善にも有効に働く結果となっ たが、その際のフィードバック方法の違いには差異はなく、書き直し作文に影響を及 ぼさないことが示された。

キーワード :

日本語中上級学習者、ライティング、教師フィードバック、作文添削、 自己訂正 


\section{日本語中上級学習者の作文に対する \\ 内容、言語形式を改善させる教師の訂正フィードバック}

\section{飯田 由美 \\ 香港中文大学専業進修学院}

\section{1. 研究背景}

第二言語の日本語作文の授業では、作文の授業を担当している教師から、作文添削 は時間がかかって大変だという声をよく聞く。また、時間をかけて作文訂正を行って も学習者は教師の訂正にあまり注意せず、同じ誤用を繰り返すことも多い。さらに、 作文を見ただけではその文章を書いた学習者の意図が不明なこともあり、学習者に真 意を確認してからでなければ適切なフィードバックは難しいが、その時間を授業時間 内で取ることはできない、などの声もある。石橋（2002b）では、教師は逸脱に気づい ても修正しない場合も多く、実際に行われた修正は文法や表記などの表層レべルの誤 用に集中していたこと、また、学習者の作文で言語形式等の誤用が原因で理解が難し い籄所については、教師が内容を想像して訂正することが多いことも報告されている。 また、広瀬（2010）では、言語形式が不適切なために書き手の意図が推測できない箇 所への添削者の解釈は、書き手の意図とずれた形で様々な推測を示し、修正方法も多 様であること、また、そうした添削者の解釈の多様性は、読み手としての添削者の一 方向的な応答としての添削の限界を示していると指摘している。以上から、学習者の 真意を必ずしも正しく反映しているとは言えない教師添削が作文上達や推敲に、実際、 効果があるのかに疑問を感じた。本稿では教師の添削負担を軽減しながら、同時に日 本語中上級学習者の作文の内容と言語形式を改善させるためには、どのような フィードバックを行えばよいのかについて調査し考察する。

\section{2. 先行研究の概要}

先行研究を（1）教師の作文フィードバック方法、(2) 学習者間の話し合いによる作 文修正、これら 2 つ観点から概観する。

まず (1) 作文指導におけるフィードバックに関しては、様々な研究が行われてきた。 教師の添削は言語習得に効果がないとする研究（Truscott， 1996）がある一方、効果 があると主張する研究もある（Ashwe11，2000; Chandler, 2003; Sachs \& Polio, 2007; Sheen，2007)。Truscott（1996）は、教師の添削は、表面的な誤りを指摘しているに すぎず、根幹にある言語習得の問題を無視しており、有害でさえあると結論付けてい る。また、発話に対するエラー修正に比べて、作文指導における教師のフィード バックにそれほど効果が見られない理由として Sheen（2007）は、学習者が作文を 
書いた直後にフィードバックを受けることはほとんどなく、フィードバックを受ける までに時間がかかるため、間違い直後に修正される発話と比べて、学習者の認知的な 負担が大きいこと等を挙げている。

教師のフィードバック方法の違いが、学習者の書き直し作文にどのような影響を 与えるのかに関しても数多くの先行研究がある。Ferris \& Roberts（2001）では、誤 用箇所に下線を引き間違いの種類を指摘する訂正方法と、間違いの場所を下線で示す だけの方法では、修正率の差異は見られず、間違いの場所を下線で示すだけでも学習 者は正しく自己訂正ができるという結果になった。Chandler (2003)では、教師が間違 いを指摘して正解を書く訂正方法が、書き直し後のエラー数が最も少ないという結果 になったが、エラー籄所を下線で示す方法も教師訂正の次に正確さの向上が見られ、 自分で修正することが可能な上級レベル学習者にとっては有用だという。Sachs \& Polio（2007）も同様の結果を示しており、教師による修正のほうが模範作文を提示 する等の他の方法よりも正確な修正ができたという結果となった。

また明示的、非明示的教師訂正の影響に関しては、学習者の誤用を正しく訂正する 直接的なフィードバックよりも、下線等を引いて誤用箇所を示寸等の間接的なフィー ドバックのほうが長期的には学習者の言語形式習得に有効であるとする先行研究 (Ashwe11，2000； Ferris，2002）もある。

二つめは（2）学習者間の話し合いによる作文修正の観点からの先行研究である。 日本語学習者を対象にピア・レスポンスを行い、作文の評価を実施した先行研究には、 池田（1999）、広瀬（2004）、原田（2006）、田中（2008）、川上（2009）がある。ピア・ レスポンスとは池田（2004）によると、「学習者が自分たちの作文をより良いものにし ていくために仲間（peer）同士で読み合い、意見交換や情報提供（response）を行い ながら、作文を完成させていく活動方法」（p. 37）である。池田（1999）は、3つの異 なる推敲方法 (自己推敲、教師フィードバック推敲、ピア・レスポンス推敲)によって どのように書き直しされたのかを調査した。全体的な評価以外に、分析的評価項目は 「内容」「語彙」「構成」「文法」を設定した。その結果、全体的評価では、成績上位 グループ、下位グループ共にピア・レスポンス推敲が最も素点が向上していた。また、 注目す心゙きなのは、教師フィードバックによる「文法」訂正にだけは、両グループと も全く素点の向上が見られなかったことである。しかし、教師フィードバックで、ど のようなフィードバックがされたのか明示されていないため、この結果がピア・レス ポンスと教師フィードバックの推敲方法の違いなのか、それとも、与えられたフィー ドバック内容による違いなのかは明確ではない（太田ら，2012）。 


\section{日本語中上級学習者の作文に対する \\ 内容、言語形式を改善させる教師の訂正フィードバック}

広瀬（2004）は、ピア・レスポンスで話されるのがどのような内容なのかを調査し た。結果、取り上げられた話題で最も多かったのは内容に関する話題であった。だが、 それにも関わらず、推敲作文にはその話し合いがほとんど反映されていなかった。そ の理由として、話された内容が具体的なアドバイスではないので作文改善に生かしに くかったこと、または、文章産出力が足りなくてできなかったこと等が報告されてい る。しかし、もし仮に、ピア・レスポンスで内容面の推敲を行うという明確な指示を 与え推敲活動を行えば、話し合いの内容を書き直し作文に反映しやすかったのではな いだろうか。

原田（2006）は、中級日本語学習者を対象にピア・レスポンスによる推敲グループ と教師添削グループに分け、書き直し作文の結果を比較した。教師添削では誤用に下 線を引いて示す方法を基本とした。結果は、教師添削と比較し、ピア・レスポンスは 学習者の自己推敲に対して、作文の内容的な側面に有効に働くことが示された。ピア・ レスポンスの効果が「文法の正確さ」に関する自己推敲に対しても、維持あるいはや や向上している結果を見ると、ピア・レスポンスは教師添削との比較において、学習 者の自己推敲に有用であると考えられる。

田中（2008）は、日本語中上級の学習者を対象として、ピア・レスポンス後に書き 直しを行い、その推敲作文に対し教師が言語形式面の推敲をすることで、推敲原稿の 評価が向上するかを調查した。作文評価は「内容」「構成」「言語能力」の 3 項目を 5 段階評価した。ピア・レスポンスを行う際には、「ピア・レスポンスでは内容・構成 について話し合うこと、教師フィードバックでは表面的な推敲をすること」（p.6）と 明確に区別し調査対象者に話し合う内容を示した。教師の言語形式に対する訂正は下 線等を記すなどの間接的な方法が取られた。その結果、ピア・レスポンス後の推敲に より、特に「内容」の評点が向上することが明らかになった。

川上（2009）では、中級レベルの日本語学習者を対象に内容と構成に的を絞った ピア・レスポンスによる作文推敲を行い、その後、教師が言語形式面の訂正を行った。 その結果、ピア・レスポンスの際に、内容・構成面の話し合いがあまりされなかった ということが判明した。ピア・レスポンス活動中、内容を理解するために作文の言語 形式面の修正に時間を費やすことが多かったこと、また学習者が仲間からのレスポン スを積極的に推敲に役立てようとする姿勢が見られなかったことが原因であるという。 以上の先行研究より、ピア・レスポンスという活動自体が内容面の質の改善に有用なの かは疑問が残る。学習者は言語形式に関して、他の人の作文を訂正できるほどの知識が ないため内容中心の話し合いになってしまったとも考えられる。また内容推敲を促す教 師フィードバックとの比較がされていないので、ピア・レスポンスは教師フィードバッ クと比べ、内容面の改善により効果があるのかどうかは明らかにされてはいない。 


\section{3. 本研究の目的}

これまでの研究で教師添削とピア・レスポンスの両方の利点が研究されている。 間接的な教師の訂正フィードバックが言語形式面に、そして、ピア・レスポンスが内 容面の質の改善に効果があるとする研究が多い（池田，1999；原田，2006；田中， 2008)。しかし、教師が内容に関するフィードバックを与えた場合とピア・レスポンス を比較調查した研究は行なわれていない。また、フィードバック方法により、内容面、 言語形式面の質の向上にどのような違いが出るのかを比較できるように対象郡の条件 を明確に統制した調查研究はなされていない。

以上の点を踏まえ、日本語中上級学習者を調查対象とし、中作文（400 字程度）の 内容と言語形式面を改善させるフィードバックとはどのようなものかを検討する。具 体的には、以下の問題を明らかにする。

1）教師フィードバックとピア・レスポンスの違いは、書き直し作文の内容面の 改善にどのように影響するか。

2）教師のフィードバック方法（明示的、非明示的）の違いは、書き直し作文の 言語形式面の正確さにどのように影響するか。

\section{4. 調查の対象と方法}

\section{1 調査対象者の数と特徴}

香港中文大学専業進修学院の広東語を第一言語と寸る、「応用日本語」専攻の 2 年生 と 3 年生 57 名を調查対象者と寸る。香港中文大学専業進修学院は香港の高等教育機関 であり、日本における短大か専門学校に相当する。日本語学習時間は 2 年生終了時で 800 時間程度であり、日本語能力試験 N3 から N1 レベルである。 3 年生は課程終了時に おいて 1050 時間程度で、日本語能力試験 N2 から N1 レベルである。このように 57 名 の日本語能力にばらつきが見られるが、初級レベルは終了していることから中上級レ ベルであると設定した。

\section{2 調查方法}

調査対象者 57 名を 2 つのグループに分け、A グループは内容に関するフィードバッ クを、B グループは言語形式を改善するためのフィードバックを示し、総合得点およ び分析的評価項目の「内容」、「構成」「言語形式」の得点がどの程度向上するかを調 查した。2014 年 8 月から 9 月にかけて、2 年終了時と 3 年終了時の日本語学習者 57 名の協力を得て調査を実施した。57 名をグループ間で日本語能力の差が出ないように、 日本語能力試験の N3 から N1 の合格状況を考慮し、A、B、A、B、・・年振り分け、 
A グループ 30 名、B グループ 27 名の 2 グループに分けた。グループ A には「内容添削 に関する調查」に、グループB には「言語形式添削に関する調査」に参加してもらっ た。作文タイトルは「田舎の生活か都会の生活か」を設定した。設定理由はこれまで の授業で「朝型か夜型か」、「日本国内を旅行するなら飛行機か新幹線か」等の作文を 書いており、調査対象者になじみがあり書きやすいと考えたため、また日本留学試験 でも比較のテーマが出題されることから、このタイトルを設定した。

\section{2.1 調査 $1 「$ 「容」のフィードバックに関する調査}

グループ A を日本語能力に差が出ないように、日本語能力試験の成績を考慮し教師 が 15 名ずつ 2 グループ、「教師 FB」と「ピア」に分けた。各グループの編成は表 1 の 通りである。

表 $1:$ 「教師 FB」と「ピア」各グループ編成

\begin{tabular}{|c|c|c|c|}
\hline グループ & $\mathrm{N} 1$ 合格者数 & $\mathrm{N} 2$ 合格者数 & $\mathrm{N} 3$ 合格者数 \\
\hline 教師 FB & 2 名 & 11 名 & 2 名 \\
\hline ピア & 3 名 & 10 名 & 2 名 \\
\hline
\end{tabular}

「ピア」グループ 15 人中 9 名は 2 年次の作文の授業（15 週間）でピア・レスポン ス活動を経験済みである。以下、各グループの具体的なフィードバック方法例を示す。

「教師 FB」：教師が内容について改善できる箇所や情報が不足している箇所などに 下線を引いて、原稿用紙の空白に日本語でコメントを記述した。書き直しの際に、日 本語コメントが理解できない場合には、中国語で質問してもよいことを伝えた。

例： 理由は 2 つある二つは香港人は忙しすぎるからそんな時間がない。二つ めは香港の家賃が高しすぎるからだ。したがって、香港で実施したら、人 気が出ることが出来ない。

$2 つ の$ 理由は一文だけで明確に、十分に説明ができていますか?

「ピア」: 各グループ 3 名でピア・レスポンス活動を行った後で、作文推敲を実施し た。話しや寸い雾囲気を作るため、グループ分けは参加者が決定した。 5 グループ中、 2 グループ（6 人）はピア・レスポンスによる話し合いが初めてであった。その際、言 語形式についてではなく内容に関する話し合いをすることを明確に指示した。参加者 
の日本語能力の差が影響しないように、話し合いは母語である広東語を使用した。具 体的な話し合いのポイントとしては、田中（2009）を参考にし、以下の 3 点を指示し た。また、これらの指示を学習者が誤解しないように中国語の訳もつけた。ピア未経 験の 2 グループには調査対象者がピア・レスポンスを理解するまで、広東語を使用し ながら説明し、簡単なピアの練習を 5 分程度実施した。

読み手：仲間の作文のいいところ、上手だと思うところを言いましょう。

読み手：仲間の作文のわかりにくいところや、作文をよくするためのアドバイス などを書きましょう。

書き手：相談したいところを言い、それについてお互いに話し合いましょう。

調査対象者が 1 時間で作文を書いた後、作文を回収し教師 2 名が作文評価基準に基 づいて評価を行った。グループ間の日本語能力に差がないことを確認するために、初 稿の成績を分散分析した結果、グループ間に有意な差は認められなかった。その後、 「教師 FB」の作文については、教師 2 名が相談し内容を改善するために適切だと思わ れるコメントを書き込んだ。1 週間以内に推敲活動を実施し 30 分で書き直しを行なっ た。調査対象者は教師が書いた内容に関するコメントを見てから作文推敲を実施した。 「ピア」グループは広瀬（2004）と同様、一人の作文につき 10 分程度の話し合いをし、 その後、話し合ったことを元に作文の書き直しを行った。 5 グループ中、3 グループか らは話し合いの様子を記録してもよいという許可が得られたため、録音と録画も実施 した。書き直しされた作文は全て回収し 2 名の教師が作文評価基準に基づいて再度、 評価を行った。

\section{2.2 調査 2 「言語形式」のフィードバックに関する調査}

グループ B の 27 名を「明示的 FB」 13 名と「非明示的 FB」 14 名の 2 グループに分け て、作文の言語形式に関する添削調査を実施した。グループ分けはグループ A 同様、 日本語能力に差が出ないように日本語能力試験の成績を考慮し、教師が表 2 のように 分けた。

表 2：「明示的 FB」と「非明示的 FB」各グループ編成

\begin{tabular}{|c|c|c|c|}
\hline グループ & N1 合格者数 & N2 合格者数 & N3 合格者数 \\
\hline 明示的 FB & 2 名 & 9 名 & 2 名 \\
\hline 非明示的 FB & 2 名 & 10 名 & 2 名 \\
\hline
\end{tabular}


各グループの具体的なフィードバック方法例を以下に示す。

「明示的 FB」：教師が全ての誤用箇所を正しく訂正する。誤用箇所に下線を引き、 その下に正しい答えを示す。

例 : 香港でそのような企業はない。

に

「非明示的 FB」：教師は全ての誤用箇所に下線のみを引く。

調査対象者が作文を書いた後、全ての作文を回収し 2 名の教師が作文評価基準に基 づいて評価を行った。グループ間の日本語能力に差がないことを確認するために、初 稿の成績を分散分析した結果、グループ間に有意な差は認められなかった。その後、 教師は作文添削を同時に行った。1 週間以内に教師添削を参考に 30 分で書き直しを実 施した。書き直しされた作文は全て回収し、2 名の教師が再度評価を行った。

\section{2.3 評価、データ分析の基準}

作文評価基準は分析的評価基準を用い、構成要素として内容・構成・言語形式の 3 項目を設定した。表 3 が採点基準であり、石橋（2002a）、田中（2008）等を参考に作 成した。また 2 年次の作文の授業でもこの評価基準は使用されており、教師が高評価 寸る作文とはどのようなものか、調査対象者に十分理解されていると考えたため、こ れを使用することにした。 
表 3 : 作文評価基準

\begin{tabular}{|c|c|c|c|c|}
\hline & 4 点 & 3 点 & 2 点 & 1 点 \\
\hline $\begin{array}{l}\text { 内容 } \\
\text { 主張・根拠 }\end{array}$ & $\begin{array}{l}\text { 主張、根拠が明確 } \\
\text { に具体的に述べら } \\
\text { れており、結論と } \\
\text { それ以前の文の流 } \\
\text { れの間に論理的一 } \\
\text { 貫性があり、非常 } \\
\text { に説得力がある。 }\end{array}$ & $\begin{array}{l}\text { 主張、根拠が述べ } \\
\text { られており、結論 } \\
\text { とそれ以前の文の } \\
\text { 流れの間に一貫性 } \\
\text { はあるが、根拠が } \\
\text { 説得的（根拠の説 } \\
\text { 明に納得できる） } \\
\text { ではない。 }\end{array}$ & $\begin{array}{l}\text { 主張、根拠が述べ } \\
\text { られてるが、最 } \\
\text { 初に述べたこと } \\
\text { と、結論が一致し } \\
\text { ていなく、一貫性 } \\
\text { がない。また根拠 } \\
\text { が説得的（根拠の } \\
\text { 説明に納得でき } \\
\text { る）ではない。 }\end{array}$ & $\begin{array}{l}\text { 主張は述べられて } \\
\text { いるが、根拠の記 } \\
\text { 述がない。または、 } \\
\text { 根拠の記述がある } \\
\text { が、意味がわから } \\
\text { ない。そのため、 } \\
\text { 結論とそれ以前の } \\
\text { 文の流れの間に一 } \\
\text { 貫性がなく、説得 } \\
\text { 的（根拠の説明に } \\
\text { 納得できる）では } \\
\text { ない。 }\end{array}$ \\
\hline 構成 & $\begin{array}{l}\text { 接続詞をうまく使 } \\
\text { 用し、段落構成・ } \\
\text { 意味関係が適切で } \\
\text { あり、問題がない。 }\end{array}$ & $\begin{array}{l}\text { 接続詞の使用の有 } \\
\text { 無、使用法にかか } \\
\text { わらず、段落構 } \\
\text { 成・意味関係が適 } \\
\text { 切であり、問題が } \\
\text { ない。 }\end{array}$ & $\begin{array}{l}\text { 接続詞の使用の有 } \\
\text { 無、使用法にかか } \\
\text { わらず、段落構 } \\
\text { 成・意味関係でつ } \\
\text { ながりの悪い箇所 } \\
\text { が一部ある。 }\end{array}$ & $\begin{array}{l}\text { 接続詞の使用の有 } \\
\text { 無、使用法にかか } \\
\text { わらず、全体的に } \\
\text { 段落意識がない、 } \\
\text { または意味関係で } \\
\text { つがりがとれて } \\
\text { いない。 }\end{array}$ \\
\hline $\begin{array}{l}\text { 言語 } \\
\text { 形式 }\end{array}$ & $\begin{array}{l}\text { 表記規則を守り、 } \\
\text { 書き言葉で丁寧に } \\
\text { 書け、レポートに } \\
\text { 使われるような日 } \\
\text { 本語能力試験 N2 } \\
\text { レベルの語彙、表 } \\
\text { 現、文型が適切に } \\
\text { 使用されている。 }\end{array}$ & $\begin{array}{l}\text { 表記規則を守り、 } \\
\text { 書き言葉であり、 } \\
\text { 日本語能力試験 N3 } \\
\text { レベルの語彙、表 } \\
\text { 現、文型が適切に } \\
\text { 使用されている。 }\end{array}$ & $\begin{array}{l}\text { 表記規則に多少不 } \\
\text { 適切な部 分があ } \\
\text { り、話し言葉が使 } \\
\text { 用されているが、 } \\
\text { 日本語能力試験 N3 } \\
\text { レ゙ルの語彙、表 } \\
\text { 現、文型が適切に } \\
\text { 使用されているた } \\
\text { め、伝達上の支障 } \\
\text { がない。 }\end{array}$ & 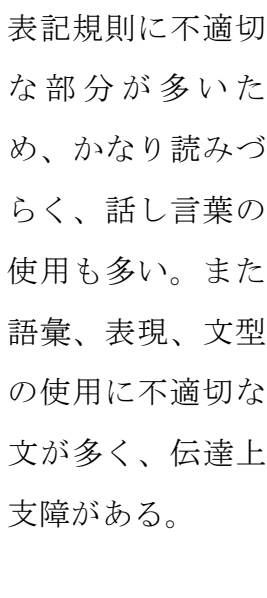 \\
\hline
\end{tabular}


各項目が添削方法により、それぞれどの程度向上したのかを調査した。修正前後と も同じ教師が添削することによって、事後の評価が甘くなるのを防ぐために、本調查 には 3 名の日本人教師（教師 A，B，C）が評価に関わった。教師 A，B は大学などの高 等教育機関にて 10 年以上、教師 C は 8 年の日本語教師経験を持つ。初稿評価は教師 $\mathrm{A}$ とC、修正後の評価は教師 B と C が行なった。最初に教師 3 名の評価基準を一致させ た後で、調查対象者の作文を独立して評価した。評価が異なるものについては話し合 いの上、妥当であると思われる方に統一した。教師 3 名の評価基準を合わせるために、 2014 年 5 月中旬から下旬にかけて評価を合わせる話し合いと練習を行った。調查対象 者と同レベルの学習者 3 名が書いた日本語中作文を用いて評価基準を話し合った。そ の後、調査対象者と同レベルの学習者が書いた 10 名分の作文を採点し、3 名の評価の 一致度が 0.90 以上になることを確認してから本調査の採点を行った。調査 2 言語形式 の訂正に関する調査については、書き直しされた作文における修正率（正しく自己修 正できた誤用数、誤って修正した誤用数、修正されなかった誤用数の割合）も算出し た。

\section{5. 結果と分析}

表 4 は調査 1 と調査 2 の各グループの初稿と修正後の作文に対する 2 名の日本語教 師による全体評価平均值と「内容」、構成」、「言語形式」の各項目の分析的評価平均 值である。

表 4 : 修正前後の総合得点と各項目の得点平均値と標準偏差 (SD)

\begin{tabular}{lccccccccc}
\hline & & \multicolumn{2}{c}{ 総合得点 } & \multicolumn{2}{c}{ 内容 } & \multicolumn{2}{c}{ 構成 } & \multicolumn{2}{c}{ 言語形式 } \\
& & 修正前 & 修正後 & 修正前 & 修正後 & 修正前 & 修正後 & 修正前 & 修正後 \\
\hline $\mathrm{A}:$ 教師 FB & 平均 & 7.67 & 8.67 & 2.73 & 3.13 & 2.60 & 2.93 & 2.33 & 2.60 \\
$(n=15)$ & $S D$ & 2.15 & 2.05 & 0.68 & 0.62 & 0.88 & 0.93 & 0.87 & 0.80 \\
\hline $\mathrm{A}:$ ピア & 平均 & 7.47 & 7.67 & 2.53 & 2.67 & 2.53 & 2.60 & 2.40 & 2.40 \\
$(n=15)$ & $S D$ & 1.89 & 1.78 & 0.62 & 0.47 & 0.81 & 0.80 & 0.71 & 0.71 \\
\hline $\mathrm{B}:$ 明示的 FB & 平均 & 7.31 & 8.62 & 2.46 & 2.77 & 2.54 & 2.92 & 2.31 & 2.92 \\
$\quad(n=13)$ & $S D$ & 1.73 & 0.92 & 0.63 & 0.42 & 0.50 & 0.27 & 0.82 & 0.47 \\
\hline $\mathrm{B}:$ 非明示的 $\mathrm{FB}$ & 平均 & 7.07 & 8.21 & 2.50 & 2.71 & 2.57 & 2.71 & 2.00 & 2.79 \\
$\quad(n=14)$ & $S D$ & 1.79 & 1.21 & 0.73 & 0.45 & 0.62 & 0.45 & 0.85 & 0.56 \\
\hline
\end{tabular}


総合得点平均值に関しては、全てのグループにおいて書き直し後に向上しているの がわかる。それぞれの修正前後の総合得点平均值の差は、「A：教師 FB」(1.00)、「A： ピア」(0.20)、「B : 明示的 FB」(1.31)、「B : 非明示的 FB」(1.14) で、「B : 明示的 FB」 グループが、特に総合得点平均值が上昇している。このグループにおける各項目の得 点平均值の上昇は、「内容」が 0.31 点、「構成」が 0.38 点、「言語形式」では、修正前 後で 0.61 点の上昇が見られた。総合得点平均值の上昇が最も少なかったのは「A：ピ ア」である。ピアグループの各項目の得点平均值の上昇は、「内容」が 0.14 点、「構成」 が 0.07 点、「言語形式」では、修正前後で得点の上昇は見られなかった。ピア・レス ポンスによる推敲は作文の内容的な側面に有効に働くという先行研究とは異なる結果 となり、教師が言語形式を修正するために正しい形式を提示したほうが、書き直し後 の「内容」「構成」「「言語形式」面、全ての得点平均值が上昇した。「B：非明示的 FB」 でも、総合得点平均值が 1.14 点上昇し、 4 グループの中で 2 番目に高い上昇を示して いる。このグループの各項目の得点平均值の上昇は「内容」が 0.21 点、「構成」が 0.14 点、「言語形式」では修正前後で 0.79 点もの上昇が見られたことからも、「言語形式」 が正しく修正されることで、「内容」「構成」ともに得点が上昇する傾向があることが 示された。これは言語形式が正しく修正されたことで、段落間のつながりがよくなり、 内容が正確に読み取れるようになったことが原因であると考える。書き手の意図の推 測が困難な箇所が減少したことで、内容理解が容易になったと言えるだろう。言語形 式に注意を払わなければならない段階にある学習者の作文では言語形式が改善される ことで、内容面の質も同時に改善され、総合得点も上昇するという結果となった。

\section{1 調査 1 の結果と分析}

表 5 と表 6 は、「A : 教師 $\mathrm{FB}$ 」、「A：ピア」各グループの総合得点と内容、構成、言 語形式それぞれの得点平均值と標準偏差 $(S D)$ である。

表 $5:$ 「教師 $F B 」 の$ 総合得点、内容、構成、言語形式の各得点平均値と $S D$

\begin{tabular}{|c|c|c|c|c|c|c|c|c|c|}
\hline & & \multicolumn{2}{|c|}{ 総合得点 } & \multicolumn{2}{|c|}{ 内容 } & \multicolumn{2}{|c|}{ 構成 } & \multicolumn{2}{|c|}{ 言語形式 } \\
\hline & & 修正前 & 修正後 & 修正前 & 修正後 & 修正前 & 修正後 & 修正前 & 修正後 \\
\hline 教師 FB & 平均 & 7. 67 & 8.67 & 2.73 & 3.13 & 2.60 & 2.93 & 2.33 & 2.60 \\
\hline$(n=15)$ & $S D$ & 2.15 & 2.05 & 0.68 & 0.62 & 0.88 & 0.93 & 0.87 & 0.80 \\
\hline \multicolumn{10}{|c|}{ 表 6 :「ピア」 } \\
\hline & & \multicolumn{2}{|c|}{ 総合得点 } & \multicolumn{2}{|c|}{ 内容 } & \multicolumn{2}{|c|}{ 構成 } & \multicolumn{2}{|c|}{ 言語形式 } \\
\hline & & 修正前 & 修正後 & 修正前 & 修正後 & 修正前 & 修正後 & 修正前 & 修正後 \\
\hline ピア & 平均 & 7. 47 & 7. 67 & 2.53 & 2.67 & 2.53 & 2.60 & 2.40 & 2. 40 \\
\hline$(n=15)$ & $S D$ & 1.89 & 1.78 & 0.62 & 0.47 & 0.81 & 0.80 & 0.71 & 0.71 \\
\hline
\end{tabular}


「教師 FB」では、修正前後で総合得点平均值が 1.00 点、内容得点平均值が 0.40 点、 構成得点平均值が 0.33 点、言語形式得点平均值が 0.27 点上昇した。内容に関するフ イードバックしか書き込まなかったのだが、3 項目とも得点平均值が上昇した。「ピア」 では修正前後で総合得点平均值が 0.20 点、内容得点平均值が 0.14 点、構成得点平均 值が 0.07 点、言語形式得点平均值が全く変化しなかった。ピア・レスポンスは内容面 の改善に有効に㗢くという先行研究とは異なる結果となった。

話し合いの内容だが、言語形式面の誤用を訂正しようと話し合っているグループも 見られたが、全グループが内容面の話に時間を費やしていたことが確認できた。にも かかわらず、その話し合いの内容が作文の質の改善につながっていないことが分かる。 また書き直し作文には、学習者と教師が考える好ましい内容にずれを感じた作文も あった。教師は話題に焦点を絞ってあり具体的な内容の作文を高評価する傾向がある のだが、学習者は一つの作文に様々な内容を取り込みがちであり、書き直し後には内 容に深みが感じられない表面的な作文になってしまったものもあった。学習者が考え る好ましい作文と今回評価に関った 3 名の教師が高評価する作文内容との間に差異が あることが原因だと考えられる。調查参加者は教師が高評価する作文について、2 年 次の作文の授業で十分説明を受けていたはずなのだが、このような結果となった。 もう一つの理由は 30 分間の話し合いのうち、言語形式面の問題から 10 分以上も作文 内容理解に時間を費やしていたことである。2 グループはピア・レスポンス開始後、 10 分以上沈黙し、互いの作文内容理解に努め質問し合っているのが確認できた。この 2 グループはピアによる話し合いを授業で経験済みであったのだが、言語形式面の問 題から内容に関する話し合いをするまでに時間がかかってしまっていた。

続いて「内容」「構成」「言語形式」項目に与える教師フィードバックとピアフィー ドバックの違いと修正前後の時間差の影響を分析するために、 $2 \times 2$ の分散分析を行っ た。その結果の概要を表 7 に示す。

まず、「内容」項目においては、フィードバック方法の違い $(F(1,28)=2.734, p=.109)$ にも修正前後の時間差にも $(F(1,28)=6.400, p=.017)$ 有意な主効果が認められなかっ た。同様に「構成」項目でも、フィードバック方法の違い $(F(1,28)=0.434, p=.516)$ にも修正前後の時間差 $(F(1,28)=3.273, p=.081)$ にも有意な主効果が認められなかっ た。 
表 $7:$ A グループ分散分析の結果

\begin{tabular}{|c|c|c|c|c|c|c|c|}
\hline & & \multicolumn{2}{|c|}{ 教師 FB } & \multicolumn{2}{|c|}{ ピア } & \multirow{2}{*}{$\begin{array}{c}\text { グループ間 } \\
\text { 主効果 }\end{array}$} & \multirow{2}{*}{$\begin{array}{c}\text { 修正前後 } \\
\text { 時間差 } \\
\text { 主効果 }\end{array}$} \\
\hline & & 平均 & $S D$ & 平均 & $S D$ & & \\
\hline \multirow[t]{2}{*}{ 内容 } & 修正前 & 2. 73 & 0.68 & 2.53 & 0.62 & \multirow[b]{2}{*}{$n s$} & \multirow{2}{*}{$n s$} \\
\hline & 修正後 & 3.13 & 0.62 & 2.67 & 0.47 & & \\
\hline \multirow[t]{2}{*}{ 構成 } & 修正前 & 2.60 & 0.88 & 2.53 & 0.81 & \multirow{2}{*}{$n s$} & \multirow{2}{*}{$n s$} \\
\hline & 修正後 & 2. 93 & 0.93 & 2.60 & 0.80 & & \\
\hline \multirow[t]{2}{*}{ 言語形式 } & 修正前 & 2. 33 & 0.87 & 2. 40 & 0.71 & \multirow{2}{*}{$n s$} & \multirow{2}{*}{$n s$} \\
\hline & 修正後 & 2. 60 & 0.80 & 2. 40 & 0.71 & & \\
\hline
\end{tabular}

$* p<.0167$

また「言語形式」項目についても同様、フィードバック方法の違い $(F(1,28)=0.054, p=.82)$ にも修正前後の時間差 $(F(1,28)=5.091, p=.032)$ にも主効果 が認められなかった。このことから、「教師 FB」と「ピア」の推敲方法の違いが、書 き直し作文の質の改善に影響を及ぼしているとは考えられない。

\section{2 調査 2 の結果と分析}

「明示的 FB」「非明示的 FB」各グループの総合得点と内容、構成、言語形式それぞれ の得点平均值を表 8 、表 9 に示す。

「明示的 FB」では前述したように、修正前後で総合得点平均值が 1.31 点、内容得点 平均值が 0.31 点、構成得点平均值が 0.38 点、言語形式得点平均值が 0.61 点上昇した。 言語形式の誤用に対し正しい答えを提示しただけだが、3 項目とも得点平均值が上昇 した。内容を改善するために教師がコメントを書き込んだ「教師 FB」と比較しても、 言語形式を修正しただけで、作文の質全体が大きく改善されたことが分かる。

\section{表 $8:$ 「明示的 FB」の総合得点、内容、構成、言語形式の各平均值と $S D$}

\begin{tabular}{cccccccccc}
\hline & \multicolumn{2}{c}{ 総合得点 } & \multicolumn{2}{c}{ 内容 } & \multicolumn{2}{c}{ 構成 } & \multicolumn{3}{c}{ 言語形式 } \\
& & 修正前 & 修正後 & 修正前 & 修正後 & 修正前 & 修正後 & 修正前 & 修正後 \\
\hline 明示的 & 平均 & 7.31 & 8.62 & 2.46 & 2.77 & 2.54 & 2.92 & 2.31 & 2.92 \\
$(n=13)$ & $S D$ & 1.73 & 0.92 & 0.63 & 0.42 & 0.50 & 0.27 & 0.82 & 0.47 \\
\hline
\end{tabular}




\section{表 9 :「非明示的 FB」の総合得点、内容、構成、言語形式の各平均値と $S D$}

\begin{tabular}{cccccccccc}
\hline & \multicolumn{2}{c}{ 総合得点 } & \multicolumn{2}{c}{ 内容 } & \multicolumn{2}{c}{ 構成 } & \multicolumn{3}{c}{ 言語形式 } \\
& & 修正前 & 修正後 & 修正前 & 修正後 & 修正前 & 修正後 & 修正前 & 修正後 \\
\hline 非明示的 & 平均 & 7.07 & 8.21 & 2.50 & 2.71 & 2.57 & 2.71 & 2.00 & 2.79 \\
$(n=14)$ & $S D$ & 1.79 & 1.21 & 0.73 & 0.45 & 0.62 & 0.45 & 0.85 & 0.56 \\
\hline
\end{tabular}

「非明示的 FB」では修正前後で総合得点平均值が 1.14 点、内容得点平均值が 0.21 点、構成得点平均值が 0.14 点、言語形式得点平均值が 0.79 点上昇した。分析的評価 において、このグループの「言語形式」が最も得点上昇が高かった結果となる。「明示 的 $\mathrm{FB} 」 の$ 修正後の言語形式得点平均值の上昇值である 0.61 点と比較しても、言語形 式が大きく改善されたと言えよう。

最も顕著に見られたのは、語彙の修正であった。正しく修正できた誤用数 220 のう ち、44（20\%）は語彙修正で、初稿では誤った語彙を使用していたのだが、書き直し後 の原稿では正しい語彙が使用されていた。また、「明示的 FB」では教師が誤用を一つ ひとつ正しい言語形式に訂正したが、「非明示的 FB」では理解不明な箇所があった場 合には節全体に下線を引いて示した。調査対象者はその下線だけが引かれた箇所を見 て、自己の日本語能力を活用し正しい言語形式への修正を試みた。その結果、単語一 つひとつではなく主語と述語をひとまとまりとした節全体が改善され、意味が理解で きるようになった部分が 12 箇所確認できた。以上 2 点が、非明示的フィードバックに おいて言語形式得点平均值を大きく上昇させた原因であると考えられる。

続いて調査 1 と同様に、明示的 FB と非明示的 FB の違いと修正前後の時間差の影響 を分析するために、 $2 \times 2$ の分散分析を行った。その結果の概要が表 10 である。

まず、「内容」項目においては、フィードバック方法の違い $(F(1,25)=0.002, p=.967)$ にも「修正前」と「修正後」の時間差 $(F(1,25)=5.031, p=.034)$ にも有意な主効果が 認められなかった。

表 $10:$ B グループ分散分析の結果

\begin{tabular}{|c|c|c|c|c|c|c|c|}
\hline & & \multicolumn{2}{|c|}{ 明示的 } & \multicolumn{2}{|c|}{ 非明示的 } & \multirow{2}{*}{$\begin{array}{c}\text { グループ間 } \\
\text { 主効果 }\end{array}$} & \multirow{2}{*}{$\begin{array}{c}\text { 修正前後 } \\
\text { 時間差 } \\
\text { 主効果 }\end{array}$} \\
\hline & & 平均 & $S D$ & 平均 & $S D$ & & \\
\hline \multirow[t]{2}{*}{ 内容 } & 修正前 & 2. 46 & 0.63 & 2.50 & 0.73 & \multirow{2}{*}{$n s$} & \multirow[b]{2}{*}{$n s$} \\
\hline & 修正後 & 2. 77 & 0.42 & 2. 71 & 0.45 & & \\
\hline \multirow[t]{2}{*}{ 構成 } & 修正前 & 2. 54 & 0.50 & 2.57 & 0.62 & \multirow{2}{*}{$n s$} & \multirow[t]{2}{*}{ * } \\
\hline & 修正後 & 2.92 & 0.27 & 2. 71 & 0.45 & & \\
\hline \multirow[t]{2}{*}{ 言語形式 } & 修正前 & 2. 31 & 0.82 & 2. 00 & 0.85 & \multirow{2}{*}{$n s$} & \multirow[t]{2}{*}{$* *$} \\
\hline & 修正後 & 2.92 & 0.47 & 2. 79 & 0.56 & & \\
\hline
\end{tabular}

$* p<.0167, * * p<.001$ 
次に「構成」項目では、「修正前」と「修正後」の時間差に主効果が認められた $(F(1,25)=9.786, p=.004)$ が、グループ間効果は認められなかった $(F(1,25)=0.259$, $p=.615)$ 。最後に「言語形式」項目についても同様、「修正前」と「修正後」の時間差 に主効果が認められた $(F(1,25)=24.625, p<.001)$ が、グループ間効果は認められなか った $(F(1,25)=0.863, p=.362)$ この結果から、フィードバック形式の違いに関わらず、 言語形式に関するフィードバックを受けて書き直すことは、作文の「構成」、「言語形 式」面の質の改善に有用であると言えるが、その訂正方法の違いは大きな影響を及ぼ さないことが分かった。

明示的訂正と非明示的訂正では、教師が添削に要する時間的負担が大きく異なる。 また教師が正しい答えを提示する方法では、作文中の意味の理解に苦しむ箇所では教 師が学習者の意図を読み取る必要があり、学習者の意図と異なった訂正をする可能性 もある。誤用箇所に下線を引くフィードバック方法なら、学習者の意図と異なった訂 正をすることもなくなり、時間的にもより効率的である。よって、誤用箇所に下線を 引いて提示するだけでも、作文の質の改善に十分な効果が得られると考える。

それでは「明示的 FB」と「非明示的 FB」の誤用修正率に差異はあるのだろうか。各 グループの誤用修正率を示したのが表 11 と表 12 である。

結果から述べると、「明示的 FB」の方が書き直し作文における誤用を正しく修正で きた割合 $(98.80 \%)$ が高かった。

表 $11:$ 「明示的 FB」言語形式の総誤用数および修正数とその割合

\begin{tabular}{cccc}
\hline & $\begin{array}{c}\text { 正しく修正できた } \\
\text { 誈誤用数 }\end{array}$ & $\begin{array}{c}\text { 誤って修正した } \\
\text { 誤用数 }\end{array}$ & $\begin{array}{c}\text { 修正されなかった } \\
\text { 誤用数 }\end{array}$ \\
\hline 333 & $329(98.80 \%)$ & $2(0.60 \%)$ & $2(0.60 \%)$ \\
\hline
\end{tabular}

表 12 :「非明示的FB」言語形式の総誤用数および修正数とその割合

\begin{tabular}{cccc}
\hline & $\begin{array}{c}\text { 正しく修正できた } \\
\text { 誤用数 }\end{array}$ & $\begin{array}{c}\text { 誤って修正した } \\
\text { 㥖誤用数 }\end{array}$ & $\begin{array}{c}\text { 修正されなかった } \\
\text { 誤用数 }\end{array}$ \\
\hline 274 & $220(80.29 \%)$ & $46(16.79 \%)$ & $8(2.92 \%)$ \\
\hline
\end{tabular}

だが、非明示的訂正でも、80.29\%の誤用を正しく修正できたことは注目すべきであ る。調査参加者の中には非明示的フィードバックを初めて体験したものも多くおり、 下線のみが引かれた原稿用紙に戸惑っている様子も見られた。今回の調査では 1 回の 書き直しのみ調査し、長期的にはどのような効果があるのかは明らかにしてはいない が、言語形式に関するフィードバックは誤用箇所に下線を引いて提示するだけでも、 十分な効果があると言えるのではないだろうか。 


\section{6. 結論と今後の課題}

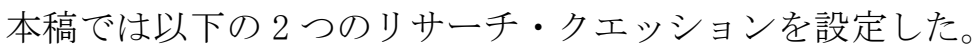

1）教師フィードバックとピア・レスポンスの違いは、書き直し作文の内容面の 改善にどのように影響するか。

2）教師のフィードバックの方法（明示的、非明示的）の違いは、書き直し作文 の言語形式面の正確さにどのように影響するか。

まず 1）であるが、教師が内容を改善するためのコメントを書き込み、それを見て 書き直し作業を行ったグループの内容得点平均值の方が、ピア・レスポンスを行った グループの内容得点平均值より高かった。

2）に関しては、明示的訂正の方が非明示的訂正よりも正しく修正できた誤用修正率 が高かった。また「言語形式」を改善すると、「構成面」の質の改善にも有効に働く結 果となったが、教師のフィードバック方法の違いが書き直し作文に与える影響につい ては、有意差が認められなかった。

本稿の結果を実際の授業に活かす方法としては、言語形式の修正に非明示的フィー ドバックを取り入れることが考えられる。誤用箇所に下線を引くだけの方法なら、ど のような授業においても実施は可能であり、また作文の「内容」「構成」「言語形式」 を改善する効果も見られる。さらに、教師の作文添削にかける時間を短縮でき、教師 負担を軽減することができるのではないだろうか。

今後の研究方向としては 2 つると考える。まず、教師訂正とピア・レスポンス効 果の比較に関し、より信頼性の高い結果を得るために、調査対象者全員がピア・レス ポンス活動に慣れている状態で調査を行なうことである。本調査では、「ピア」グルー プのうち、9 名の調査参加者は作文の授業（15 週）でピアを経験済みであったが、6 名の参加者は今回の調査で初めてピア・レスポンスを体験した。よって、全員が確実 にピア・レスポンス活動を理解しているとは言いがたい。教師フィードバックとピア・ レスポンスのどちらがより内容面の改善に有用かを調査するためには、調査参加者全 員がピア・レスポンス活動に慣れていることが条件となる。その上で、再度、教師訂 正との比較を行なうべきである。

もう一つはフィードバック方法の違いにより、どのような言語形式項目が自己修正 可能なのか、また、学習者の修正にどのような差異が生じるかである。石橋（2008） は、表層レベルの訂正における自己訂正では文体の訂正が一番多かったと述べている が、その他の具体的な語彙や文法項目については明確にされてはいない。以上の 2 点 を今後の課題としたい。 


\section{参考文献}

池田玲子(1999)「日本語作文におけるピア・レスポンスの効果一中級学習者の場合一」『言語文化と

日本語教育』17, 36-47

池田玲子(2004)「日本語学習における学習者同士の相互助言（ピア・レスポンス）」『日本語学』

23.1, 36-50

石橋玲子(2000)「日本語学習者の作文におけるモニター能力ー産出作文の自己訂正から」『日本語

教育』106 号 56-65

石橋玲子(2002a)『第 2 言語習得における第 1 言語の関与』風間書房

石橋玲子(2002b)「日本語学習者の産出作文に対する教師の修正及び非修正行動」『言語文化と日本語

教育』23, $1-12$

石橋玲子(2008)「作文推敲過程からみる自己訂正、教師添削の効果一気づきの観点からー」『タイ国

日本研究国際シンポジウム 2007 論文報告書』221-236

太田裕子・佐渡島紗織・冨永敦子・齋藤綾子(2012)「大学初年次日本語アカデミック・ライティング

授業における留学生と帰国生の文章力一初回課題と最終回課題の文章 評価調査から一」早稲田

大学国際教養学部紀要『Waseda Global Forum』8, 337-375

川上麻理(2009)「内容と構成に的を絞ったピア・レスポンスー学習者の反応から見た活動の改善点

一」『ICU 日本語教育研究』 6 号 63-72

田中信之(2008)「ピア・レスポンスの効果一作文プロダクトの観点からー」『応用言語学研究論集』

2, $1-10$

田中信之(2009)「自律的な書き手を育成する活動としてのピア・レスポンスー学習者のピア・レス

ポンスへの適応過程の分析を通してー」『アカデミック・ジャパニーズ・ジャーナル』1 号 25-36

原田三千代(2006)「中級学習者の作文推敲過程に与えるピア・レスポンスの影響一教師添削との比較

一」『日本語教育』131, 3-12

広瀬和佳子(2004)「ピア・レスポンスは推敲作文にどう反映されるかーマレーシア人中級日本語学習

者の場合一」『第二言語としての日本語の習得研究』7, 60-80

広瀬和佳子(2010)「学習者の作文に対寸る解釈の多様性と「添削」の限界一日本語教師の添削過程の

分析を中心に一」『早稲田日本語教育学』8, 29-43

Ashwell, T. (2000). Patterns of teacher response to student writing in a multiple-draft composition classroom:

Is content feedback followed by form feedback the best method? Journal of Second Language Writing, 9, 227-257.

Chandler, J. (2003). The efficacy of various kinds of error feedback for improvement in the accuracy and fluency of L2 student writing. Journal of Second Language Writing, 12(3), 267-296.

Ferris, D.R. (2002). Treatment of error in second language student writing. Ann Arbor: University of Michigan Press.

Ferris, D.R., \& Roberts, B. (2001). Error feedback in L2 writing classes: How explicit does it need to be? Journal of Second Language Writing, 10(3), 161-184.

Qi, D.S., \& Lapkin, S. (2001). Exploring the role of noticing in a three-stage second language writing task. Journal of Second Language Writing, 10(4), 277-303.

Sachs, R., \& Polio, C. (2007). Learners' uses of two types of written feedback on a L2 writing revision task. Studies in Second Language Acquisition, 29(1), 67-100.

Sheen, Y. (2007). The effects of focused written corrective feedback and language aptitude on ESL learners' acquisition of articles. TESOL Quarterly, 41(2), 255-283.

Truscott, J. (1996). The case against grammar correction in L2 writing classes. Language Learning, 46, 327-369. 